SVU- International Journal of Veterinary Sciences, 2 (2): 52-70, 2019.

\title{
Molecular Detection of Some Virulence Genes in Pseudomonas aeruginosa Isolated from Chicken Embryos and Broilers with regard to Disinfectant Resistance
}

Hala S. Shahat ${ }^{1}$, Hams M.A. Mohamed ${ }^{2^{\star}}$, Mohammed W. Abd Al-Azeem ${ }^{2}$, Soad A. Nasef ${ }^{3}$

${ }^{1}$ Reference Laboratory for Veterinary Quality Control on Poultry production (RLQP), Animal Health Research Institute, Luxor branch, Egypt, ${ }^{2}$ Department of Microbiology, Faculty of Veterinary Medicine, South Valley University 83523 Qena, Egypt, ${ }^{3}$ Reference Laboratory for Veterinary Quality Control on Poultry production (RLQP), Animal Health Research Institute, Dokki, Giza 12618, Egypt.

\section{Abstract}

Pseudomonas is a communal motif of environmental associated disease and causes a serious problem in poultry farms, so this study was deliberated to investigate the quandary of Pseudomonas species especially Pseudomonas aeruginosa ( $P$. aeruginosa) which has multifarious virulence genes and plays a major role in poultry outbreaks. Also, it focuses the light on the problem of antimicrobial and disinfectant resistance. A total of 200 samples (100 from dead in shell chicken embryos and 100 from broilers at different ages) were collected from different hatcheries and farms in Luxor governorate, 40 isolates (20\%) of Pseudomonas species were isolated and identified serologically as P.cepacia, P.fluorescens, P.putida, P.fragi and P.aeruginosa. PCR inveterate the existence of P.aeruginosa DNA in seven isolates by using $16 \mathrm{SrDNA}$ primers at 956bp. P.aeruginosa isolates have different virulence genes such as toxA, exoS, lasB, lasI and oprL gene with incidence rate $71.42 \%$ for each of them, except oprL was $100 \%$. Also, Quaternary Ammonium Compounds resistant genes (QACs) were detected in $P$. aeruginosa isolates with incidence rate $(14.28 \%)$ for each of qacAB and qacCD genes, while the qacEDl gene incidence was $(100 \%)$. P. aeruginosa isolates showed an obstacle of antimicrobial resistance for different antimicrobials while most of these isolates cleared susceptibility for ciprofloxacin and norfloxacin. In conclusion, this work described the problem of $P$. aeruginosa as it proved a high virulence repertoire owned by the $P$. aeruginosa that confirming its pathogenicity for chicken embryos and broilers. Also, our study is fuelling the concern on disinfectant resistance problem and displaying the relation between QACs and antibiotic resistance. So, the deterrence of the Pseudomonas infection in the poultry housing becomes necessary by applying strict bio-security measures.

Keywords: Antimicrobials, P.aeruginosa, QACs resistant genes, Virulence genes.

DOI: $10.21608 / \mathrm{svu} .2019 .12365 .1011$

Received: April 28, $2019 \quad$ Accepted: June 26, 2019

Published: July 5, 2019

*Corresponding Author: Hams M. A. Mohamed E-mail: hams.mohamed@vet.svu.edu.eg

Citation: Shahat et al., Molecular Detection of Some Virulence Genes in Pseudomonas aeruginosa Isolated

from Chicken Embryos and Broilers with regard to Disinfectant Resistance. SVU-IJVS 2019, 2 (2): 52-70.

Copyright: (C) Shahat et al., This is an open access article distributed under the terms of the creative common attribution license, which permits unrestricted use, distribution and reproduction in any medium provided the original author and source are created.

Competing interest: The authors have declared that no competing interest exists. 


\section{Introduction}

Pseudomonas species play an effective role in the poultry industry of all ages. The major leading of pseudomonas species causing poultry outbreaks, especially in chicks, was Pseudomonas aeruginosa (P.aeruginosa) which is a gram-negative, a motile, non-spore forming rods (Elsayed et al., 2016). It is characterized by producing of watery soluble green pigment with a specific fruity odor.

The hatchery is the leading source for the prevasion of diseases within the poultry industry. The problem constantly starts with contaminated eggs which are incubated under exemplary condition for microbiological growth. Various bacterial pathogens that contaminate hatcheries have been isolated from dead in shell embryos (Bakheet et al., 2017). P.aeruginosa was considered a profiteer pathogen, leads to respiratory infections, septicemia and mortalities in chickens and embryos (Dinev et al., 2013 and Eman et al., 2017). It is always listed as the head most of three frequent Gram-negative pathogens and is linked to the worst visual diseases. Its outbreak varies from 2 to $100 \%$ (Fick, 1993, John Barnes, 1997 and Saad et al., 2017).

P. aeruginosa has got a massive armory of virulence repertoire such as lipopolysaccharide, elastase, alkaline proteases, pyocyanin, pyoverdin, hemolysins, phospholipase $\mathrm{C}$ and rhamnolipids. These factors are coordinated by a global regulatory system which is activated by autoinducers involved (lasI) gene (Kebede, 2010 and Habeeb et al., 2012). Also exoS, exoT, exoU, and exoY genes that regulate the action of $P$. aeruginosa type III secretion system which injects toxic effectors proteins into the cytosol of host cells and accompanied by inferior clinical outcomes and elevated mortality rates (Hauser, 2009).

$P$. aeruginosa uses the virulence factor exotoxin A to inactivate eukaryotic elongation factor 2 in the cell, such as the diphtheria toxin does, hence eukaryotes can't synthesize protein and necrotize (Eman et al., 2017). Since the powerful toxins released during bacteremia as continuing to infection even after $P$. aeruginosa has been killed off by antibiotics (Kirienko et al., 2015).

One of the main troublesome characters of $P$. aeruginosa is a minor susceptibility to a lot of types of antimicrobials, making it a very hard pathogen to eliminate and this because $P$. aeruginosa genome contains the largest known resistance island genes (Balasubramanian et al., 2013 and Khattab et al., 2015). The important reason for antimicrobial resistance was impermeability which belongs to the outer membrane lipoprotein (oprL gene) that implicated in efflux transport systems and affects cell permeability (De Vos et al., 1997).

Antibiotics are profusely administered for therapeutic and prophylaxis purposes in veterinary field (Dandachi et al., 2018). In recent years, disinfectants have been used with carelessness that leading to the adaptation of bacteria and augmenting the spread of resistant bacteria. P. aeruginosa isolates were found to be resistant to quaternary ammonium compounds (QACs) (Loughlin et al., 2002). It was found that QACs resistance genes were combined decisively with genes coding for resistance to Sulphonamides, Trimethoprim, Chloramphenicol, Aminoglycosides and $\beta$ lactams (Zhao et al., 2012 and Schill et al., 2017).

Therefore the intent of this study was the characterization of P.aeruginosa isolated from chicken embryos and 
broilers, with focusing a high light on virulence and disinfectant resistance genes, in addition to determining the susceptibility of P.aurgienosa strains for different antimicrobials.

\section{Materials and Methods}

\section{Samples Collection:}

A total of 200 samples included liver heart and yolk sac were collected from 100 dead in-shell chicken embryos and 100 broilers (50 baby chicks and 50 broilers) from different hatcheries and farms in Luxor governorate for isolation and identification of Pseudomonas spp., most of the cases suffered from diarrhea, yellowish nasal secretion, ruffled feather and conjunctivitis. All samples were handled aseptically to prevent crosscontamination using sterile sampling materials according to (Middleton et al., 2005). The period of work extended from November 2017 to May 2018.

\section{Isolation and Biochemical identification of pseudomonas spp.:}

One gram from each sample was inoculated in a tube containing $9 \mathrm{ml}$ Peptone buffer water (PBW) and incubated at $37^{\circ} \mathrm{C}$ for $24 \mathrm{hrs}$ then a loopful PBW was streaked onto Trypticase soy agar and was incubated at $37^{\circ} \mathrm{C}$ for $24-48$ hours, The suspected colonies were refined on MacConkey agar and Pseudomonas agar media at $37^{\circ} \mathrm{C}$ for $24 \mathrm{~h}$. $P$. aeruginosa isolation was done according to (Shukla and Mishra, 2015). The suspected colonies were subjected to different biochemical tests such as oxidase test, catalase test, arginine hydrolysis test, gelatin liquefaction, Indol, methyl red and urease test (Cheesbrough, 2000).

\section{Serological identification:}

Serotyping of the isolated Pseudomonas spp. was applied by using slide agglutination technique (specific 4 polyvalent and 16 monovalent antisera) according to the recommendation of the manufacturer's protocol (Bio-Rad ${ }^{\circledR}$, France) according to Glupczynski et al., (2010). The apportionment of $P$. aeruginosa into groups based on P.aeruginosa $\mathrm{O}$ antisera, relayed on the International Antigen Typing Scheme (IATS) according to Legakis et al. (1982).

\section{Antibiotic Sensitivity Test:}

The antimicrobial sensitivity test was performed according to Finegold and Martin (1982) by using the disc diffusion method. Different antimicrobials were used such as Tetracycline, Erythromycin, Ampicillin, Amoxicillin, Sulphamethazone, Nalidixic acid, Streptomycin, Gentamycin, Ciprofloxacin and Norfloxacin. The interpretation of the measured zone was done according to CLSI (2018).

\section{DNA Extraction:}

$P$. aeruginosa DNA was extracted according to QIAamp DNA mini kit instructions.

\section{Amplification of $P$. aeruginosa $16 S$ rDNA:}

The amplification of $P$. aeruginosa $16 S$ rDNA was done by using specific primers,

F- 5'GGGGGATCTTCGGACCTCA3'and R- 5'TCCTTAGAGTGCCCACCCG3' (Spilker et al., 2004) which targeted fragment size 956bp (Table .1). These primers were utilized in a $25 \mu \mathrm{l}$ reaction containing 12.5 $\mu$ l of Emerald Amp Max PCR Mastermix (Takara, Japan), $1 \mu \mathrm{l}$ of each primer of $20 \mathrm{pmol}$ concentrations, 4.5 $\mu \mathrm{l}$ of water and $6 \mu \mathrm{l}$ of the template. The 
PCR cycles consisted of preheating at $94^{\circ} \mathrm{C}$ for $5 \mathrm{~min}$, denaturation at $94^{\circ} \mathrm{C}$ for 30 sec, annealing at $52^{\circ} \mathrm{C}$ for $45 \mathrm{sec}$, extension at $72^{\circ} \mathrm{C}$ for $1 \mathrm{~min}$ and final extension $72^{\circ} \mathrm{C}$ for $10 \mathrm{~min}$. The amplification was performed for 30 cycles in a Biometra thermal cycler. The PCR products were separated by electrophoresis in $1.5 \%$ agarose gel (ABgene). A 100 bp DNA Ladder (Qiagen, USA) determines the fragment sizes. The gel was pictured by a documentation system and the data was saved by computer software.

\section{Molecular detection of virulence and disinfectant resistant genes in $P$. aeruginosa isolates}

Eight sets of Pseudomonas spp. primers were utilized in the study and are listed in Table (1). These primers sequences (Metabion,Germany) were deduced from different genes such as outer membrane protein (oprL), exotoxin A (toxA), exotoxinS (exoS), elastase (lasB) and autoinducer gene (lasI) and the Quaternary ammonium compound (QACs) resistance genes $(q a c A / B, q a c C / D$ and $q a c E D 1)$. The different PCR reactions used for these primers were optimizing in a $25 \mu \mathrm{l}$ mixture consisting of $12.5 \mu \mathrm{l}$ of Emerald Amp Max PCR Master Mix (Takara, Japan), $1 \mu$ of each primer (20 pmol conc.), $4.5 \mu \mathrm{l}$ of water and $6 \mu \mathrm{l}$ of DNA template. The reaction was implemented in a Biometra thermal cycler. PCR analysis was done on $P$. aeruginosa strains by using a reaction that used the $45^{\circ} \mathrm{C}$ for $5^{\circ} \mathrm{C}$ initial denaturation temperature then denaturation $94^{\circ} \mathrm{C}$ for 30 seconds. The annealing temperature was adjusted according to the suitable conditions for each gene's primers as following: $72^{\circ} \mathrm{C}$ for $45-\mathrm{sec}$ toxA, and oprL primers, $55^{\circ} \mathrm{C}$ for $30 \mathrm{sec}$ exoS primers, $57^{\circ} \mathrm{C}$ for 40 -sec lasB primers and $56^{\circ} \mathrm{C}$ for 40 -sec lasI primers. While the annealing temperature for QACs genes was $53^{\circ} \mathrm{C}$ for 40 -sec $Q a c A / B, 53^{\circ} \mathrm{C}$ for $30 \mathrm{sec} Q a c C / D$ and $58^{\circ} \mathrm{C}$ for 40 sec QacED1. DNA extension and final extension was done at $72^{\circ} \mathrm{C}$, the consumed time differs according to primers condition (Supporting data). PCR products were separated on $1.5 \%$ agarose gel (AB gene). A 100 bp DNA Ladder (Qiagen, USA) defined the fragment sizes. The gel was visualized through a documentation system.

Table (1): Oligonucleotide primers for virulence and disinfectant resistant genes of P.aeruginosa.

\begin{tabular}{|c|c|c|c|}
\hline Primer & Sequence $5^{\prime}-3^{\prime}$ & $\begin{array}{c}\text { Amplified } \\
\text { product }\end{array}$ & Reference \\
\hline \multirow{2}{*}{$\begin{array}{c}16 S \\
r D N A\end{array}$} & F- GGGGGATCTTCGGACCTCA & \multirow{2}{*}{$956 \mathrm{bp}$} & \multirow{2}{*}{$\begin{array}{l}\text { (Spilker et } \\
\text { al., 2004) }\end{array}$} \\
\hline & R- TCCTTAGAGTGCCCACCCG & & \\
\hline \multirow{2}{*}{ toxA } & GACAACGCCCTCAGCATCACCAGC & \multirow{2}{*}{$396 \mathrm{bp}$} & \multirow{2}{*}{$\begin{array}{c}\text { (Matar et al., } \\
\text { 2002) }\end{array}$} \\
\hline & CGCTGGCCCATTCGCTCCAGCGCT & & \\
\hline \multirow{2}{*}{ lasB } & ACAGGTAGAACGCACGGTTG & \multirow{2}{*}{$1220 \mathrm{bp}$} & \multirow{2}{*}{$\begin{array}{c}\text { (Finnan et al., } \\
\text { 2004) }\end{array}$} \\
\hline & GATCGACGTGTCCAAACTCC & & \\
\hline \multirow{2}{*}{ lasI } & ATGATCGTACAAATTGGTCGGC & \multirow{2}{*}{$606 \mathrm{bp}$} & \multirow{2}{*}{$\begin{array}{c}\text { (Bratu et al., } \\
\text { 2006) }\end{array}$} \\
\hline & GTCATGAAACCGCCAGTCG & & \\
\hline \multirow[b]{2}{*}{ exos } & GCGAGGTCAGCAGAGTATCG & \multirow[b]{2}{*}{$118 \mathrm{bp}$} & \multirow{2}{*}{$\begin{array}{l}\text { (Winstanley } \\
\text { et al., 2005) }\end{array}$} \\
\hline & TTCGGCGTCACTGTGGATGC & & \\
\hline \multirow{2}{*}{ oprL } & ATG GAA ATG CTG AAA TTC GGC & \multirow{2}{*}{$504 \mathrm{bp}$} & \multirow{2}{*}{$\begin{array}{c}\text { (Xu et al., } \\
2004)\end{array}$} \\
\hline & CTT CTT CAG CTC GAC GCG ACG & & \\
\hline
\end{tabular}


Shahat et al., 2019

SVU-IJVS, 2 (2): 52-70

\begin{tabular}{|c|c|c|c|}
\hline \multirow[t]{2}{*}{ qacED1 } & TAA GCC CTA CAC AAA TTG GGA GAT AT & \multirow{2}{*}{$362 \mathrm{bp}$} & \multirow{2}{*}{$\begin{array}{l}\text { (Chuanchuen } \\
\text { et al., 2007) }\end{array}$} \\
\hline & GCC TCC GCA GCG ACT TCC ACG & & \\
\hline \multirow{2}{*}{$q a c A / B$} & GCAGAAAGTGCAGAGTTCG & \multirow{2}{*}{$361 \mathrm{bp}$} & \multirow{4}{*}{$\begin{array}{l}\text { (Noguchi et } \\
\text { al., 2005) }\end{array}$} \\
\hline & CCAGTCCAATCATGCCTG & & \\
\hline \multirow{2}{*}{ qacC/D } & GCCATAAGTACTGAAGTTATTGGA & \multirow{2}{*}{$195 \mathrm{bp}$} & \\
\hline & GACTACGGTTGTTAAGACTAAACCT & & \\
\hline
\end{tabular}

\section{Results}

\section{Isolation and identification of P.aeruginosa}

The results of bacteriological examination for 200 samples (100 from dead embryos and 100 from broilers at different ages), cleared that 40 samples (20\%) showed a green-blue color colonies with a sweet grape-like odor of Pseudomonas spp. were developed on Pseudomonas agar media and didn't ferment lactose sugar in MacConkey agar, also it was noticed that the incidence of Pseudomonas spp. was higher in dead embryos and baby chicks in age from 1day to10 days than other ages (Table 2).
Different biochemical tests were used to identify Pseudomonas spp, Ps. Aeruginosa showed a clear positive result for oxidase test, catalase test, Citrate reaction, arginine hydrolysis (gives brown color) and gelatin liquefaction but is negative to indole production, methyl red reaction and Voges Proskauer test. $P$. aeruginosa produces pyocyanin and pyoverdin pigments, grows well at $42^{\circ} \mathrm{C}$ and $4^{\circ} \mathrm{C}$ and gives red butt and slant without $\mathrm{H} 2 \mathrm{~S}$ production on triple sugar iron agar. But the biochemical scheme cannot separate other species due to the high resemblance among the results of isolates so further identification was done by serological test and PCR to reach to accurate species.

Table (2): The incidence of Pseudomonas spp. isolated from examined samples:

\begin{tabular}{|c|c|c|c|c|}
\hline Age & $\begin{array}{l}\text { Types of } \\
\text { samples }\end{array}$ & $\begin{array}{l}\text { No. of examined } \\
\text { samples }\end{array}$ & $\begin{array}{c}\text { No. of } \\
\text { isolates }\end{array}$ & Frequency \\
\hline Dead in-shell chicken embryos & Yolk sac & 100 & 19 & $19 \%$ \\
\hline $\begin{array}{l}\text { Broilers } \\
\text { Young chicks (1-10 days) } \\
\text { Old broilers (11-35 days) }\end{array}$ & $\begin{array}{l}\text { Yolk sac, } \\
\text { Liver and } \\
\text { heart }\end{array}$ & $\begin{array}{l}\mathbf{5 0} \\
\mathbf{5 0}\end{array}$ & $\begin{array}{c}21 \\
0\end{array}$ & $\begin{array}{c}42 \% \\
0 \%\end{array}$ \\
\hline Total & --- & 200 & 40 & $20 \%$ \\
\hline
\end{tabular}

Serological identification of 40 isolates suspected Pseudomonas spp. were explicated in table (3) showed that 35 isolates only belonged to Pseudomonas spp. and 5 isolates were unidentified serologically. Identified isolates were subtended to $P$. aeruginosa (7isolates), P.cepacia (8isolates), P. fluorescens (11isolates), P.putida (7 isolates) and P.fragi (2isolates) (Table 3) furthermore P.aeruginosa strains according to (IATS) were divided into 4 serotypes P.aeruginosa O2, O6, O10 and O11 (Table 4).
Table (3): serological identification of Pseudomonas species:

\begin{tabular}{|l|c|}
\hline \multicolumn{2}{|c|}{$\begin{array}{c}\text { Identified Pseudomonas spp. } \\
\text { Total (no.35 isolates) }\end{array}$} \\
\hline Pseudomonas aeruginosa & $7(20 \%)$ \\
\hline Pseudomonas cepacia & $8(22 \%)$ \\
\hline Pseudomonas fluorescens & $11(31 \%)$ \\
\hline Pseudomonas putida & $7(20 \%)$ \\
\hline Pseudomonas fragi & $2(5.7 \%)$ \\
\hline
\end{tabular}


Table (4): Serogrouping of P.aeruginosa isolated from chicken samples:

\begin{tabular}{|c|c|}
\hline Serotypes of $\boldsymbol{P}$. aeruginosa & Group \\
\hline P. aeruginosa O10 & H \\
\hline$P$. aeruginosa O6 & G \\
\hline P. aeruginosa O11 & E \\
\hline P.aeruginosa O11 & E \\
\hline$P$. aeruginosa O6 & G \\
\hline P. aeruginosa O2 & G \\
\hline$P$. aeruginos $\mathrm{O} 11$ & E \\
\hline
\end{tabular}

II. Susceptibility of $P$. aeruginosa for different antimicrobials:

Table (5) demonstrated that an obvious resistance was noted against Erythromycin, Ampicillin, Tetracycline, Amoxicillin and Sulphamethazone (100\%) and was followed by Nalidixic acid (57.1\%) and Streptomycin (42.9\%). Only one isolate was resistant to Gentamycin (14.3\%). On the other hand, the highest sensitivity was observed against Ciprofloxacin (100\%) and Norfloxacin (71.4\%), so they were considered the most influential antibiotics.

Table (5): The interpretation of antimicrobial resistance of $P$. aeruginosa isolates according to CLSI (2018).

\begin{tabular}{|c|c|c|c|c|c|c|c|}
\hline \multirow{2}{*}{ Antimicrobial agents } & \multirow{2}{*}{ Conc. } & \multicolumn{2}{|c|}{ Resistance } & \multicolumn{2}{|c|}{ Intermediate } & \multicolumn{2}{|c|}{ Sensitive } \\
\hline & & No. & $\%$ & No. & $\%$ & No. & $\%$ \\
\hline Sulphamethazole & $100 \mu \mathrm{g}$ & 7 & $100 \%$ & --- & --- & --- & --- \\
\hline Gentamycin & $10 \mu g$ & $\mathbf{1}$ & $14.3 \%$ & 5 & $71.4 \%$ & 1 & $14.3 \%$ \\
\hline Erythromycin & $15 \mu \mathrm{g}$ & 7 & $100 \%$ & --- & --- & --- & --- \\
\hline Tetracycline & $30 \mu \mathrm{g}$ & 7 & $100 \%$ & $\begin{array}{ll}-- \\
\end{array}$ & $\begin{array}{ll}-- \\
--\end{array}$ & --- & $\begin{array}{ll}-- \\
--\end{array}$ \\
\hline Ciprofloxacin & $5 \mu \mathrm{g}$ & --- & --- & --- & $-\cdots$ & 7 & $100 \%$ \\
\hline Amoxicillin & $25 \mu \mathrm{g}$ & 7 & $100 \%$ & $-\cdots$ & --- & $-\cdots$ & --- \\
\hline Ampicillin & $10 \mu \mathrm{g}$ & 7 & $100 \%$ & --- & --- & --- & -- \\
\hline Streptomycin & $10 \mu \mathrm{g}$ & 3 & $42.9 \%$ & 4 & $57.1 \%$ & --. & --- \\
\hline Nalidixic acid & $30 \mu \mathrm{g}$ & 4 & $57.1 \%$ & 3 & $42.9 \%$ & --- & $-\cdots$ \\
\hline Norfloxacin & $10 \mu \mathrm{g}$ & --- & --- & 2 & $28.6 \%$ & 5 & $71.4 \%$ \\
\hline
\end{tabular}

III. Molecular confirmation of $P$. aeruginosa DNA by using 16SrDNA primers:

Sixteen isolates were submitted for molecular examination as follows: 7 isolates of P.aeruginosa and 4 isolates from other species (1 from each species) and 5 isolates unidentified serologically. PCR results confirmed the existence of P.aureginosa DNA in the same seven isolates only by using $16 \mathrm{SrDNA}$ at $956 \mathrm{bp}$ (Fig. 1a, 1b).

\section{$I V$. Detection of virulence and disinfectant resistance genes in P.aeruginosa isolates:}

Only the $P$. aeruginosa isolates (7 isolates), were tested for detection of virulence and disinfectant resistance genes. Different primers were used for targeted virulence genes such as (oprL, toxA, exoS, las $B$ and lasI) resulted in amplicons $504 \mathrm{bp}$, 396bp, 118bp, 1220bp and 606bp respectively, and cleared that oprL gene was disclosed in all $P$. aeruginosa isolates with percentage of $100 \%$ (Table 6 and Fig. 2 ), while other genes were detected with the same percentage $71.4 \%$ (Table 6, Fig. 3, Fig. 4, Fig. 5, and Fig. 6), Also a group of primers was used in this study for detection of QACs resistance gene (qac $A / B$, qac $C / D$ and $q a c$ EDI) qacA/B and qacC/D genes were detected with the same percentage (14.28\%; Fig.7 and Fig. 8), while the qacED1 gene incidence was $100 \%$ as it was 
detected in all P.aeruginosa isolates (Fig. 9).
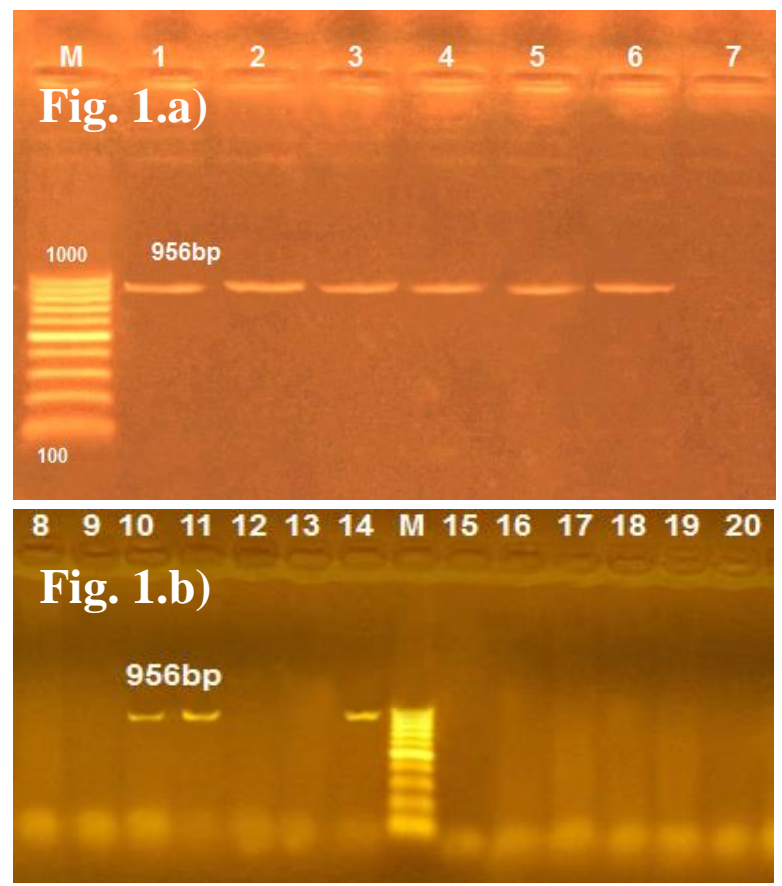

Fig. (1): Amplifying a 956bp fragment of 16S rDNA gene of P.aeruginosa isolates. M: 100bp represents ladder, lane 1 represent positive control, lanes $2,3,4,5$, and 6 represent positive isolates, and lane 7 represent negative control for $16 \mathrm{~S} r \mathrm{DNA}$ gene of P.aeruginosa (Fig. 1a); lanes 10, and 11 represent positive isolates, lane 14 represent positive control, lanes $8,9,12$, $13,15,16,17,18$, and 19 represent negative isolates and lane 20 represent negative control (No DNA) for $16 \mathrm{~S} r \mathrm{DNA}$ gene of P.aeruginosa (Fig. 1b).

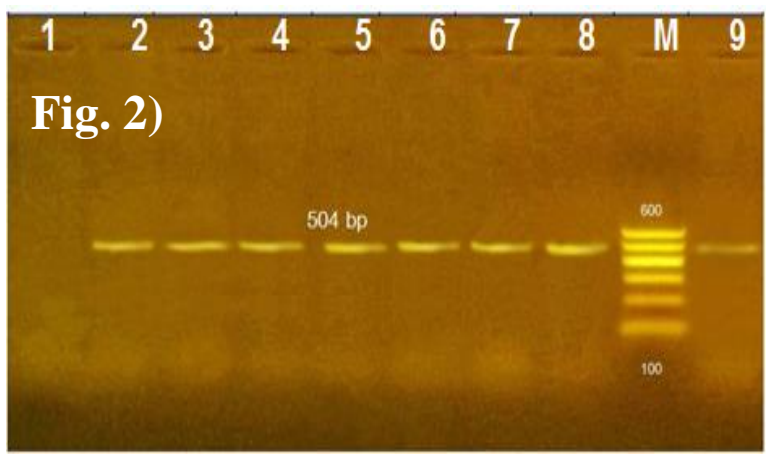

Fig. (2): Amplification profile of oprL gene of P.aeruginosa isolates at 504bp. M:100 bp represents ladder, lanes 2, 3, 4, 5,
6,7 , and 8 represent positive isolates, lane 9 represents positive control and lane 1 represents negative isolates for $\boldsymbol{o p r} L$ gene.



Fig. (3): Amplification profile of toxA gene of P.aeruginosa isolates at $396 \mathrm{bp}$. M:100bp represents ladder; lanes 2, 3, 4, 5, and 6 represent positive isolates, lanes 7 , and 8 represent negative isolates, lane 1 represents positive control, and lane 9 represent negative control for toxA gene.

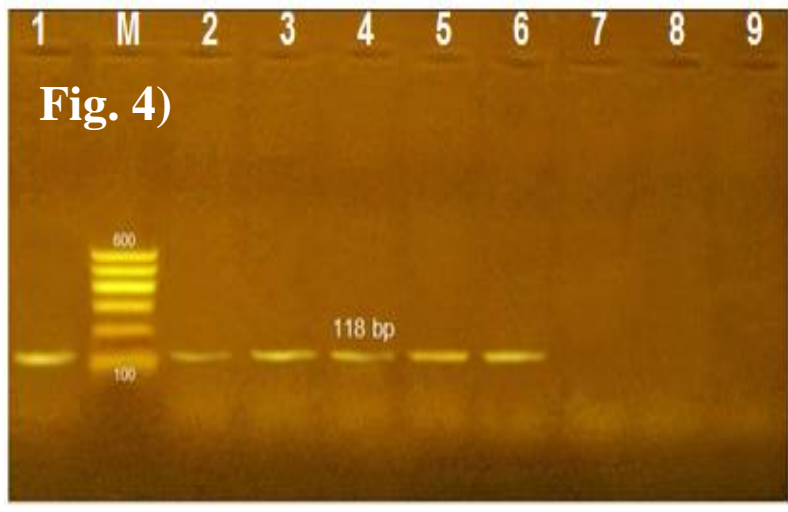

Fig. (4): Amplification profile of exoS gene of $P$.aeruginosa isolates at $118 \mathrm{bp}$. M: 100 bp represents ladder, lanes 2, 3, 4, 5 , and 6 represent positive isolates, lane 1 represents positive control, lanes 7 , and 8 represent negative isolates, and lane 9 represents negative control for $\operatorname{exoS}$ gene.

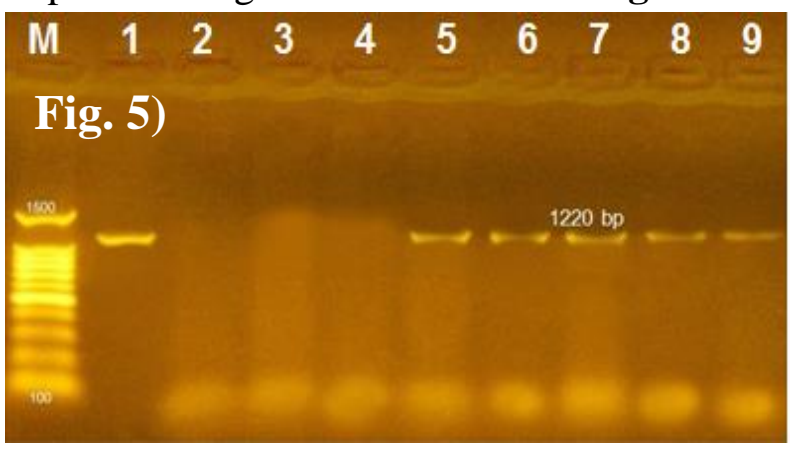


Fig. (5): Amplification profile of lasB gene of P.aeruginosa isolates at $1220 \mathrm{bp}$. M:100 bp represents ladder, lanes 5, 6, 7, 8, 9 represent positive isolates, lane 1 represent positive control and lane 2 represent negative control, and lanes 3 , and 4 represent negative isolates for las $\boldsymbol{B}$ gene.

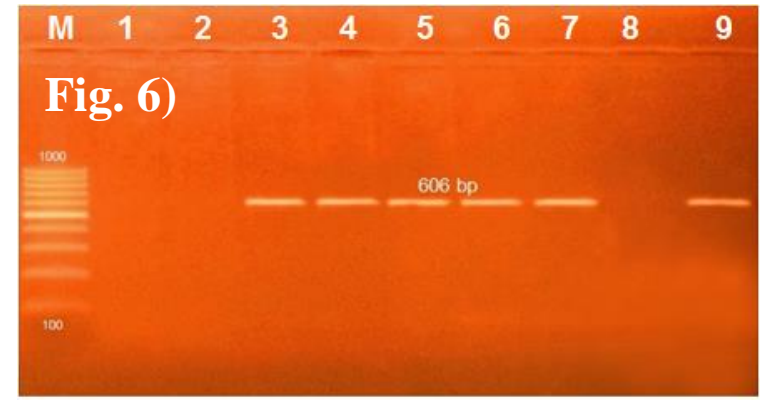

Fig. (6): Amplification profile of lasI gene of P.aeruginosa isolates at $606 \mathrm{bp}$. M:100 bp represents ladder, lanes 1 , and 2 represent negative isolates, lanes 3, 4, 5, 6, and 7 represents positive isolates, lane 8 represents negative control and lane 9 represents positive control for lasI gene.

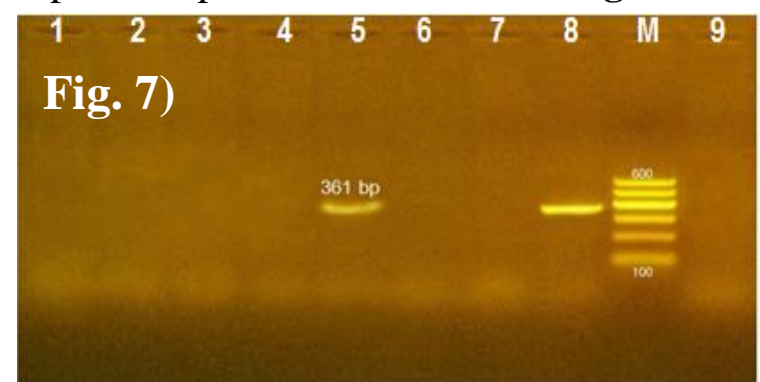

Fig. (7): Amplification profile of $q a c A / B$ gene of P.aeruginosa isolates at $361 \mathrm{bp}$. M: 100 bp represents ladder, lane 8 represents positive control, lane 5 represents positive isolate, lanes 1, 2, 3, 4, 6 , and 7 represent negative isolates and lane 9 represent negative control for $q a c A / B$ gene.

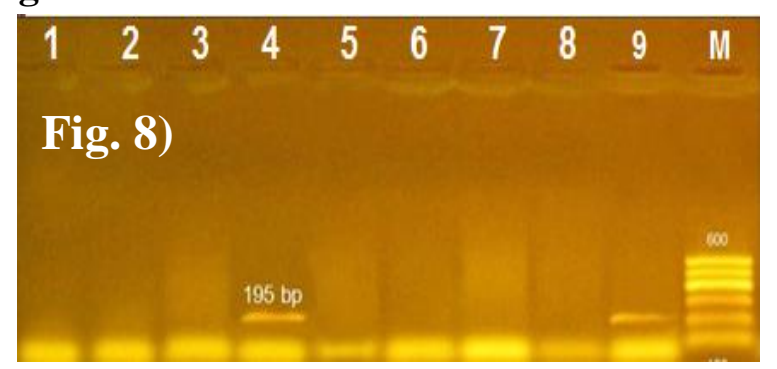

Fig. (8): Amplification profile of $q a c C / D$ gene of P.aeruginosa isolates at195bp. $\mathrm{M}$ : 100 bp represents ladder, lane 4 represents positive control, lane represents 9 positive isolate, lanes 1, 2, 3, 5, 6, and 7 represents negative isolates, and lane 8 represents negative control for $q a c C / D$ gene

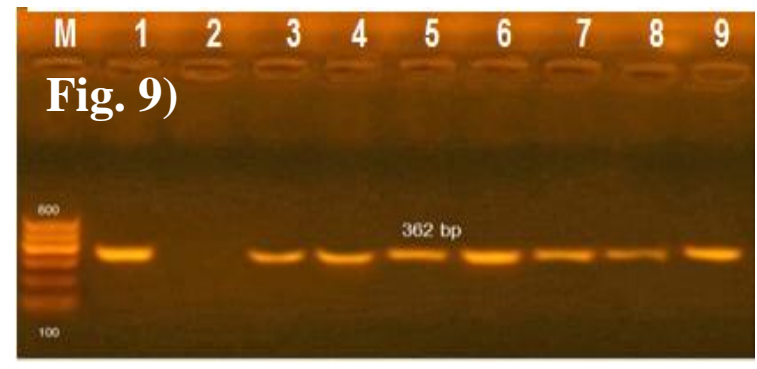

Fig. (9): Amplification profile of qacED1 gene of P.aeruginosa isolates at $362 \mathrm{bp}$. M: 100 bp represents ladder, lane 1 represents positive control, lanes $3,4,5,6$, 7,8 , and 9 represent positive isolates, and lane 2 represent negative control for qacED 1 gene.

Table (6): Distribution of virulence and QACs resistant genes in P.aeruginosa isolates:

\begin{tabular}{|l|c|}
\hline \multicolumn{1}{|c|}{ Genes } & $\begin{array}{c}\text { P.aeruginosa } \text { isolates } \\
\text { (no.7 isolates) }\end{array}$ \\
\hline OprL gene & $7(\mathbf{1 0 0 \%})$ \\
\hline toxA gene & $5(\mathbf{7 1 . 4 2 \% )}$ \\
\hline lasI gene & $5(\mathbf{7 1 . 4 2 \% )}$ \\
\hline lasB gene & $5(\mathbf{7 1 . 4 2 \% )}$ \\
\hline exoS gene & $5(\mathbf{7 1 . 4 2 \% )}$ \\
\hline qacA/B gene & $1(14.28 \%)$ \\
\hline qacC/D gene & $1(14.28 \%)$ \\
\hline qacEDI gene & $7(\mathbf{1 0 0 \% )}$ \\
\hline
\end{tabular}

\section{Discussion}

The Pseudomonas infection was considered an extensive economic problem in poultry farms, especially $P$. aeruginosa 
which causing a high mortality in birds especially chickens (Elsayed et al., 2016). The complications caused by $P$. aeruginosa in birds have appeared in the form of respiratory signs, septicemia, keratitis, sinusitis and embryonic death (Hussein et al., 2008 and Hai-ping, 2009). So, the identification of these strains should be used as a part of a threat in microbiological analysis. In this study, the prescriptive identification showed typical green-blue color colonies for Pseudomonas spp. on Pseudomonas agar media and colorless colonies on MacConkey agar media, these characters were similar to Haleem et al., (2011), also the morphological features with gram stain showed a gram-negative rods of pseudomonas spp. these findings were supported by Quinn et al., (2002) and Tripathi et al., (2011).

The results that were illustrated in table

(2) showed that the incidence of pseudomonas spp reached to $20 \%$, the higher incidences were recorded in dead embryos and broiler chicks (1-10 days) $19 \%$ and $42 \%$ respectively, in comparison with old ages (over 10 days), these results were supported by Kebede (2010) who proved experimentally that the main cause of high mortalities rate in unhatched chicken and young chicks, was the infection by $P$. aeruginosa in hatching time from the environment or by invading the eggshell of embryo leading to death. Our incidence was compatible with Saif-Eldin (1983) and Shukla and Mishra (2015) who isolated the organism from unhatched chicken eggs with a percentage of $18.8 \%$ and $19 \%$ respectively.

The lower results were obtained by Hebat-Allah (2004) who isolated $P$.aeruginosa from baby chicks and broilers at rates of $17.6 \%$ and $3.3 \%$ respectively, also Mahmoud and Mousa (2000), AbdelTawab et al. (2016) and Bakheet et al., (2017) who isolated P. aeruginosa from chicks with incidence rates $6.6 \%, 2.5 \%$ and $18.6 \%$ respectively. Higher results were obtained by Kurkure et al., (2001) who isolated P.aeruginosa from dead broiler chicks in an incidence of $57 \%$.

In our study, serological identification dissented the results of biochemical tests in number of isolates due to 35 isolates only out of 40 isolates belonged to pseudomonas spp. and five isolates were unidentified serologically, the identified isolates were classified to five species as following : $P$. aeruginosa, $P$. cepacia, $P$. fluorescens, $P$. putida and P.fragi (Table 3) also it was found that $P$. aeruginosa strains divided into different serotypes $\mathrm{O} 2, \mathrm{O} 6, \mathrm{O} 10$ and O11 by using slide agglutination technique (Table 4). Kusma (1978) confirmed the identification of heat-stable somatic antigens is the most widely used method for the serological typing of P.aeruginosa. In addition, Pitt and Erdman (1977) showed that the high specificity of $\mathrm{O}$ antisera was for P.aeruginosa serotypes. Vieu et al., (1984) mentioned that P.aeruginosa antisera are applied in serological identification of $P$. aeruginosa cultures using slide agglutination method, for epidemiological purpose. However, Lanyi (1967) found that all P.aeruginosa strains were agglutinated by the same antisera and proposed that the heat-stable antigenic determinants that responsible for polyagglutination in these strains might be identical. In this study the most clear P.aeruginosa serotypes were O6 and 11 (Table 4), convergent results were earned by Bouza et al., (2003); Hocquet et al., (2003) and Nashwa et al., (2016).

P.aeruginosa attracts the attention as an awful pathogen for consumer health of various infections in human and food animals and carries multidrug resistant traits that are transferable to other pathogens of both human and animal. The 
antimicrobial resistance is one of the most important problems confronting the world and it is elevating in developing countries. Therefore, it's important to detect $P$. aeruginosa precisely and quickly and identify its susceptibility pattern; this may avoid useless antibiotic treatment which presents antibiotic-resistant pathogens (Hamisi et al., 2012).

The antimicrobial susceptibility of $P$. aeruginosa was tested by using disc diffusion method against ten antimicrobials, the results were noted in table (5), cleared that the high resistance $(100 \%)$ was noticed against Sulphamethazone, Erythromycin, Ampicillin, Tetracycline, Amoxicillin and Erythromycin followed by Nalidixic acid (57.1\%), Streptomycin (42.9\%), these results were coincided with Walker et al., (2002); Ahmed (2016) and Tartor and Elnaenaeey (2016) who mentioned that the high resistance was found to Tetracycline, Erythromycin and Ampicillin. In opposite to Abd El-Gawad et al., (1998) who reported that $P$. aeruginosa isolates of chickens were sensitive to Tetracycline. Abdel-Tawab et al., (2016) found that P.aeruginosa isolates were resistant to Nalidixic acid (80\%).

In the current work, the high sensitivity was observed with Ciprofloxacin (100\%), Gentamycin (85\%) and Norfloxacin (71.4\%) (Table 5), these findings go hand to hand with Khan and Cerniglia (1994), Hebat-Allah (2004) and Mohammad (2013) who recorded a high sensitivity with Ciprofloxacin and Norfloxacin while a lower sensitivity of $P$. aeruginosa to Ciprofloxacin and Norfloxacin was recorded by Abd El-Tawabet et al., (2014). While Abd El-Gawad et al., (1998) and Kurkure et al., (2001) illustrated a high sensitivity to Gentamycin $(88.6 \%$ and $100 \%$ respectively).
These variations among the results may be attributable to the difference in many conditions surrounding hatcheries or may be a result of hyper-mutation which occurred frequently in P.aeruginosa strains and leading to the development of various antimicrobial resistance as reported by Maciá et al., (2005). Antibiotic-resistant bacteria (ARB) can easily spread alongside the food chain and cause most of public health hazards (Da Costa et al., 2013, FAO, 2015, WHO, 2015 and Price et al., 2012).

Qin et al., (2003) reported that the identification of $P$. aeruginosa with traditional methods takes a long time to perform and extensive hands-on work by technicians. So, the PCR method has been used to provide a specific, rapid, simple, and vastly sensitive discovery of $P$. aeruginosa.

In the present study, PCR asserted the presence of P.aeruginosa DNA in seven isolates out of 16 isolates identified serologically, by using specific primers for $P$. aeruginosa (16S rDNA) at 956bp (Fig.1a, 1b), these findings were bolstered by Spilker et al., 2004. The Confirmation of $P$. aeruginosa identification by PCR method became more important to overcome the problems of culture method such as a false negative culture result that may be owing to the sample overgrowth by other bacteria, or to the presence of noncultivable or mutant organisms (Cornelis et al., 1989; De Vos et al., 1992 and Kolmos et al., 1993)

$P$. aeruginosa has got an enormous numbers of extracellular virulence factors and cellular components which implicated in pathogenesis (Kebede, 2010 and Habeeb et al., 2012). For those reasons, this study was designed for the detection of these virulence genes (oprL, lasB, toxA, exoS and lasI) in $P$. aeruginosa isolates by using PCR. 
Concerning the results of virulence factors (Table 6), it was found that the detection of oprL gene in all our isolates (100\%) (Fig. 2) confirmed the existence of $P$ aeruginosa DNA because it considers a specific marker for molecular detection of P.aeruginosa and encodes a protein in the inner and outer membranes, which is essential for the invasion of epithelial cells (De Vos et al., 1997), the same result obtained by $\mathrm{Xu}$ et al., (2004), Abdullahi et al., (2013) and Hassan (2013) and implicated in efflux transport systems affecting cell permeability so there is a strong relationship between the detection of $o p r \mathrm{~L}$ and phenotypic antibiotic resistance that reported by Qin et al., (2003) and Lavenir et al., (2007).

In this study, the incidence rate of tox $A$ gene was $71.42 \%$, as shown in Table (6) and Fig. (3), similar results of toxA were reported by Qin $e$ al., (2003) and Lavenir et al., (2007). Khan and Cerniglia (1994) showed that $96 \%$ of tested P.aeruginosa isolates contained a toxA gene. Furthermore, the exoS and $\operatorname{las} B$ genes were detected in our study, in five isolates of P.aeruginosa ( $71.42 \%$ for each of them) (Table 6 and Fig.4 and 5) and this percentage was nearly similar to Feltman et al., (2001). Tartor and El-naenaeey (2016) who found that the colossal majority of $P$. aeruginosa isolates showed exoS gene $(78.6 \%)$. The higher percentage was recorded by Nikbin et al., (2012) who detected lasB in all strains of P.aeruginosa $(100 \%)$.

The mentioned virulence genes in this work such as, toxA, exoS and $\operatorname{las} B$ were coordinated by a critical global regulatory systems consisted of transcriptional activator protein (LasR) and Pseudomonas autoinducer, (PAI), the central gene responsible for activation of this system was putative autoinducer synthase (lasI) (Kebede, 2010 and Habeeb et al., 2012)
The lasI gene (quorum sensing Regulation gene) was detected in this existing study with a percentage $(71.42 \%)$ (Table 6 and Fig.6). Venturi (2006) reported that the lasI is not detected in any Pseudomonas spp. otherwise $P$. aeruginosa strain. Our percentage of lasI gene was less than that was detected by Alshalah et al., (2017) who succeeded in the amplification of lasI gene in all clinical isolates of P.aeruginosa. In addition to, Nikbin et al., (2012) explained that the possession of $P$. aeruginosa for several virulence genes make it a reason for various levels of virulence and pathogenicity.

Quaternary ammonium compounds (QACs) are active detergents, Since the 1930s; they widely applied in the poultry industry because of their good antibacterial properties (Haynes and Smith, 2003 and Minbiole et al., 2016). QACs commonly act by distracting the cytoplasmic and outer membrane lipid bilayers and disruption of the critical intermolecular interactions in a specific biochemical system (Tischer et al., 2012). In recent years, disinfectants have been utilized with irreverence leading to adaptation of bacteria to those products and increasing the resistant of bacteria to disinfectants, such as QACs, which make the preclusion of $P$. aeruginosa is a more complicated trouble (Loughlin et al., 2002).

Our study has focused alights on the detection of QACs resistance genes (Table.6). The results demonstrated that the incidence rate of $q a c A / B$ and $q a c C / D$ was $14.28 \%$ for each of them (Fig.7 and 8). While, the qacED1 gene incidence was $(100 \%)$ as it was detected in all isolates (Fig.9) and these results go hand to hand with Abdel-Tawab et al., (2016) and Bakheet et al., (2017) who detected by PCR the qacEDI gene in $P$. aeruginosa isolates with incidence rate $100 \%$ but these results were nearly in conformity with Amira (2016) who noticed that the qacEDl was 
distributed in most of $P$. aeruginosa isolates (93.1\%). The high percentage of qacED1 gene in $P$. aeruginosa is owing to the widely distribution of this gene in Gramnegative bacteria, mainly in Enterobacteriaeace and Pseudomonas spp. (Wang et al., 2008). Also, Longtin et al., (2011) and Zmantar et al., (2012) mentioned that $q a c A / B$ genes and $q a c C / D$ genes were predominant among Grampositive bacteria and this explained the low incidence of both $q a c A / B$ and $q a c C / D$ in our work.

The pervasive using and exposure of microorganisms to sub-MIC concentrations of QACs could be result in the disinfectant resistance and showed that the contingency of cross-resistance among disinfectants and antimicrobials has been occurred because of using QACs-based disinfectants in environments where antibiotics are used, thus fuelling the concern of a relation between QAC and antibiotic resistance (Reverdy et al., 1993 and Hegstad et al., 2010). So, it was recommended that the use of disinfectants should be the last line of defense for the poultry industry (Bakheet et al., 2017).

The QACs resistance genes are linked to the minor multidrug resistance family (Paulsen et al., 1996). QacED1 is mainly found in Gram-negative bacteria in combination with genes coding for resistance to Sulphonamides, Aminoglycosides, Chloramphenicol, $\beta$ lactams and Trimethoprim so, this leads to increasing the study of bacterial resistance to QACs in the food industry and veterinary fields (Zhao et al., 2012).

It is significant to clear that, in this study all qacEDl positive $P$. aeruginosa were multidrug resistant. These findings came in conformity with Bakheet et al., (2017) who found that all qacED1 positive $P$. aeruginosa were resistant to at least three classes of antimicrobial agents. This definites the link between QACs resistance genes and multi-drug resistance bacteria of the isolated strains, also Russel (2002) explained that the disinfectant resistance might be back to antibiotic resistance by coresistance, cross-resistance and co-selection mechanisms.

\section{Conclusion}

Our study proved that a high virulence repertoire was owned by the $P$. aeruginosa confirming its pathogenicity for chicken embryos and broilers, especially in the presence of oprL gene which plays a great role in antimicrobial resistance and qacED1 gene that reflects another complicated problem with QACs disinfectants. Therefore, this study can provide the poultry farms with suitable guidelines for the prescription of accurate antimicrobials particularly, after appearance a positive relation between antibiotic and disinfectant resistance.

\section{Acknowledgments}

The authors of this study would like to thank all members of Microbiology Department, Faculty of Veterinary Medicine, South Valley University, Egypt, for their helpful discussion and valuable comments for this manuscript. The authors would like to thank all members of the reference Lab for veterinary quality control on poultry production, Dokki, Gizza, and Luxor branch, Egypt, for their help.

\section{Conflict of interest}

The authors assert that they have no conflict of interest.

\section{References}

Abd El-Gawad AM, Ali SM, Azzaz HA (1998). Some studies on pseudomonas aeruginosa infection in 
growing chickens in Assuit farm. Assiut Veterinary Medical Journal, 38: 90-97

Abd El-Tawab AA, Fatma IE, Dalia FK, Mo'men MA (2014). PCR detection and gene sequence of Pseudomonas aeruginosa isolated from broiler chickens. Benha Veterinary Medical Journal, 27(2):449-455

Abdel-Tawab AA, Nasef AS, Ibrahim AO (2016). Bacteriological and Molecular Studies on Bacteria Causing Omphalitis in Chicks with Regard to Disinfectant Resistance. Global Veterinaria, 17 (6): 539-545.

Abdullahi R, Lihan S, Carlos BS, Bilung ML, Mikal MK, Collick F (2013). Detection of oprL gene and antibiotic resistance of Pseudomonas aeruginosa from aquaculture environment. European Journal of Experimental Biology, 3(6):148-152.

Ahmed I (2016). Studies on omphalitis in baby chicks.Thesis, Master of Veterinary Medicine, University of Beni-Suif.

Alshalah AJZ, Al-Daraghi AW, Khaleel IA (2017). Rapid Detection For lasI and lasR Genes of Pseudomonas Aeruginosa at Deference Iraqi Hospitals by Polymerase Chain Reaction (PCR) Technique.International Journal of ChemTechResearch,10 (1): 409-414.

Amira FA (2016). Molecular characterization of virulence genes in Salmonella spp. Isolated from poultry. Ph.D. Thesis, Universityof Kafrelsheikh.

Bakheet AA, Naglaa MA, Sayed HA, Soad AN (2017). Detection of Disinfectant resistant aerobic bacteria in unhatched chicken eggs.Benha Veterinary Medical Journal,32 (2): 248-259.

Balasubramanian D, Schneper L, Kumari H, Mathee K, (2013). A dynamic and intricate regulatory network determines Pseudomonas aeruginosa virulence. Nucleic Acids Research, 41:1-20.

Bouza E, Cercenado F, Marín M, Díaz MS, Sánchez Romero I, Vindel A (2003). Pseudomonas aeruginosa: a multicenter study in 136 hospitals in Spain Rev Esp. Quimioter, 16(1): 4152.

Bratu S, Gupta J, Quale J (2006). Expression of the las and rhl quorumsensing systems in clinical isolates of Pseudomonas aeruginosa does not correlate with efflux pump expression or antimicrobial resistance. Journal of Antimicrobial Chemotherapy, 58: 1250-1253.

Cheesbrough, M. (2000). Pseudomonas and related organisms.Biochemical test to identify bacteria.Antibiotic susceptibility testing. In: District Laboratory Practice in tropical countries. Cambridge University Press, New York, USA, pp. 19331943.

Chuanchuen R, Khemtong S, Padungtod (2007). Occurrence of qace/qace $\Delta 1$ gene and their correlation with class 1 integrons in salmonella enterica isolates from poultry and swine. The Southeast Asian Journal of Tropical Medicine and Public Health, 38:855862.

CLSI (2018). Performance Standards for Antimicrobial Disk Susceptibility Testing.28th ed. CLSI standard M100.Clinical and Laboratory Standards Institute; http:/ www.facm.ucl.ac.be /intranet /CLSI/CLSI-2018-M100-S28.

Cornelis P, Bouia A, Belarbi A, Guyonvarch A, Kammerer B, Hannaert V, Hubert JC (1989). Cloning and analysis of the gene for 
the major outer membrane lipoprotein from Pseudomonas aeruginosa. Molecular Microbiology, 3: 421-8.

Da Costa PM, Loureiro L, Matos, A J F (2013). Transfer of multi- drug resistant bacteria between intermingled ecological niches: the interface between humans, animals and the environment. International Journal of Environmental Research and Public Health, 10: 278-294.

Dandachi I, Sokhn ES, Dahdouh EA, Azar E, El-Bazzal B, Rolain J-M and Daoud Z (2018). Prevalence and Characterization of Multi-DrugResistant Gram-Negative Bacilli Isolated From Lebanese Poultry: A Nationwide Study. Frontiers in Microbiology, 9: 550.

De Vos D, Lim A Jr, De Vos P, Sarniguet A, Kersters K, Cornelis P (1992). Detection of the outer membrane lipoprotein I and its gene in fluorescent and non-fluorescent pseudomonads: implications for taxonomy and diagnosis. Journal of general microbiology, 139: 22152223.

De Vos D, Lim AJ, Pirnay JP, Struelens M, Vandenvelde C, Duinslaeger L, Vanderkelen A, Cornelis P(1997).Direct detection and identification of Pseudomonas aeruginosa in clinical samples such as skin biopsy specimens and expectorations by multiplex PCR based on two outer membrane lipoprotein genes, oprI and oprL. The Journal of Clinical Microbiology, 35: 1295-1299.

Dinev I, Denev S, Beev G (2013). Clinical and morphological studies on spontaneous cases of Pseudomonas aeruginosa infections in birds. The Pakistan Veterinary Journal, 33:398400.
Elsayed MSA, Ammar AM, Al Shehri ZS, Abd-El Rahman NA (2016). Virulence Repertoire of Pseudomonas aeruginosa from some Poultry Farms with Detection of Resistance to Various Antimicrobials and Plant Extracts. Cellular and Molecular Biology, 62: 124-132.

Eman MF, Heba R, Bakheet AA, Abd ElHafez SA and Heba B (2017). Advanced studies on Pseudomonas aeruginosa infection in chicken.Animal Health Research Journal, 5(4): 207-217.

FAO (2015). Status Report on Antimicrobial Resistance. Rome: Food and Agriculture Organization of the United Nations.

Feltman HS, Chulert G, Khan S, Jain M, Peterson L, Hauser AR (2001).Prevalence of type III secretion genes in clinical and environmental isolates of Pseudomonas aeruginosa. Microbiology, 147, 2659-2669.

Fick, R. (1993). Pseudomonas aeruginosathe Microbial Hyena and Its Role in Disease: An Introduciton. Pseudomonas aeruginosa: The Opportunist. pp:1-6.

Finegold, SM, Martin WG (1982). Bailey and Scott's Diagnostic Microbiology, (Ed.6) The C.V. Mosby Company. St. Louis, Toronto, London.

Finnan S, Morrissey JP, Gara FO, Boyd EF (2004). Genome Diversity of Pseudomonas aeruginosa Isolates from Cystic Fibrosis Patients and the Hospital Environment.Journal of clinical microbiology, 42(12): 578392.

Gholami A, Majidpour A, Talebi-Taher M, Boustanshenas M, Adabi M (2016). PCR-based assay for the rapid and precise distinction of 
Pseudomonas aeruginosa from other Pseudomonas species recovered from burns patients. Journal of Preventive Medicine and Hygiene, 57(2): E81-5.

Glupczynski Y, Bogaerts1 P, Deplano A, Berhin C, Huang C, Van J, Villalobos $\mathrm{H}$ (2010). Detection and characterization of class A extendedspectrum b-lactamase-producing Pseudomonas aeruginosa isolates in Belgian hospitals. Journal of antimicrobial agents and Chemotherapy, 65: 866-871.

Habeeb RH, Saad SN, Al-Jubory A (2012). A study of efficacy of disinfectants and bacterial contamination in Alhilla teaching hospital. Medical journal of Babylon, 9(4):890-900.

Hai-ping HE (2009). Isolation and identify of Pseudomonas aeruginosa in chicken dead-embryos Chinese Qinghai. Journal of animal veterinary sciences, 3: 25-27.

Haleem H, Kadhim J, Ilham T, Banyan A (2011). Isolation of Pseudomonas aeruginosa from Clinical Cases and Environmental Samples, and Analysis of its Antibiotic Resistant Spectrum at Hilla Teaching Hospital.Medical Journal of Babylon, 8: 618-624.

Hamisi Z, Tuntufye H, Shahada F (2012). Antimicrobial resistance phenotypes of Escherichia coli isolated from tropical free-range chickens. International Journal of Science and Research, 3(9): 34.

Hassan HM (2013). Characterization of Pseudomonas aeruginosa isolated from different pathological lesions in chickens. M. V. Sc. Thesis, faculty of veterinary medicine, University of Benisuef.
Hauser AR (2009). The type III secretion system of Pseudomonas aeruginosa: infection by injection.Nature Reviews Microbiolo gy. 7: 654-665.

Haynes, RL, Smith TW (2003). Hatchery management guide for game birds and small poultry flock owners. A7page online publication of Mississippi State University, www msstate.edu/dept/poultry/ hatchgmt.htm.

Hebat-Allah AM (2004). Some studies on Pseudomonas species in chicken embryos and broilers in Assiut governorate. Assiut University bulletin for environmental researches, 7(1): 23-30.

Hegstad K, Langsrud S, Lunestad BT, Scheie AA, Sunde M, Yazdankhah SP (2010). Does the wide use of quaternary ammonium compounds enhance the selection and spread of antimicrobial resistance and thus threaten our health? Microbial Drug Resistance, 16(2): 91-104.

Hocquet D, Bertrand X,Köhler T, Talon D,Plésiat P (2003). Genetic and phenotypic variations of a resistant Pseudomonas aeruginosa epidemic clone. Antimicrobial Agents and Chemotherapy, 47(6):1887- 1894.

Hussein SA, Nassan AH, Sulaiman RR (2008). Bacteriological and pathological study of yolk sak infection in broiler chicks in sulaimani district.Journal of Dohuk University, 1: 48-56

John Barnes, H. (1997). Other bacterial diseaes: Pseudomonas. In diseases of poultry, edited by Calnek B.W., John Barnes H., Beard C.W., Mcdougald L.R. \& Saif Y. M., (10 ${ }^{\text {th }}$ edition), 4: $291-292$. 
Kebede F (2010). Pseudomonas infection in chickens. Journal of Veterinary Medicine and Animal Health, 2(4): 55-58.

Khan AA, Cerniglia CE (1994). Detection of Pseudomonas aeruginosa from clinical and environmental samples by amplification of the exotoxin A gene using PCR. Applied and Environmental Microbiology, 60: 3739-3745.

Khattab MA, Nour MS, El-Sheshtawy NM (2015). Genetic identification of Pseudomonas aeruginosa virulence genes among different isolates. Journal of Microbial and Biochemical. Technology, 7: 274277.

Kirienko NV, Ausubel FM, Ruvkun G (2015). Mitophagy confers resistance to siderophore-mediated killing by Pseudomonas aeruginosa.the National Academy of Sciences of the United States of America, 112 (6): 1821-1826.

Kolmos HJ, Thuesen B, Nielsen SV, Lohmann M, Kristoffersen K, Rosdahl VT (1993). Outbreak of infection in a burn's unit due to Pseudomonas aeruginosa originating from contaminated tubing used for irrigation of patients. Journal of hospital infection, 24: 11-21.

Kurkure NV, Kalorey DR, Shubhangiwarke PS, Bhandarkar AG. (2001). Mortality in young broilers due to pseudomonas aeruginosa.Indian Journal of Veterinary Research. 10: 55-57.

Kusama H (1978). Serological Classification of Pseudomonas aeruginosa by a Slide Agglutination Test. Journal of Clinical Micrbiology, 8(2): 181-188
Lavenir R, Jocktane D, Laurent F, Nazaret S, Cournoyer B(2007).Improved reliability of Pseudomons aeruginosa PCR detection by the use of the specific ecfx gene target. Journal of Microbiology, 70: 20-29.

Legakis N, Majtan V, Wang S (1982). Serotypes of Pseudomonas aeruginosa in clinical specimens in relation to antibiotic susceptibility. Journal of Clinical. Microbiology, 16 (3): 458-463.

Lényi B (1967). Serological properties of Pseudomonas aeruginosa. I. Groupspecific somatic antigens Act amicrobiologicaL Academiae Scientiarum Hungaricae, 13: 295-318. Longtin J, Seah C, Siebert K, McGeer A,Simor A, Longtin Y, Low DE, Melano RG (2011). Distribution of antiseptic resistance genes qacA, $q a c B$, and smr in methicillin-resistant Staphylococcus aureus isolated in Toronto, Canada, from 2005 to 2009. Antimicrobial Agents and Chemotherapy 55: 2999-3001.

Loughlin MF, Jones MV, Lambert PA (2002). Pseudomonas aeruginosa cells adapted to benzalkonium chloride show resistance to other membrane- active agents but not to clinically relevant antibiotic. Journal Antimicrobial and Chemotherapy. 49: 631-639.

Maciá M D, Blanquer D, Togores B, Sauleda J, Pérez LJ, Oliver A (2005). Hypermutation Is a Key Factor in Development of MultipleAntimicrobial Resistance in Pseudomonas aeruginosa Strains Causing Chronic Lung Infections. Antimicrobial Agents and Chemotherapy, 49(8): 3382-3386 
Mahmoud AEA, Moussa HM (2000). Studies on some aerobic bacteria causing of broiler. $1^{\text {st }}$ scientific conference for provincial laboratories, Animal Health Re-search Instit., 1517 May 2000.Egyptian journal agricultural research, 78(1): 25-34

Matar GM, Ramlawi F, Hijazi N, Khneisser I, Abdelnoor AM (2002). Transcription Levels of Pseudomonas aeruginosa Exotoxin A Gene and Severity of Symptoms in Patients with Otitis Externa. Current microbiology, 45: 350-354.

Minbiole K PC, Jennings MC, Ator LE (2016). From antimicrobial activity to mechanism of resistance: the multifaceted role of simple quaternary ammonium compounds in bacterial eradication. Tetrahedron, 72(25): 3559-3566.

Middleton JR, Fales WH, Luby CD, Landsay Oaks J, Sanchez S, Kinyon JM, Wu CC, Maddox CW and Hartmann F (2005). Surveillance of Staphylococcus aureus in veterinary teaching hospitals. Journal of Clinical Microbiology, 43(6): 2916-2919.

Mohammad HH (2013) Phenotypic Investigation for Virulence factors of Pyocine producing Pseudomonas aeruginosa Isolated from Burn Wounds, Iraq. International Journal of Scientific \& Engineering Research, 4(7): 2114-21.

Nashwa AE, Samar MM, Nourah KA, Afaf AE, Mohamed AA, Seida AA, Manal FA (2016). phenotypic identification of Pseudomonas aeruginosa isolated from milk in Taif governorate and characterization of resistance to fluoroquinolones and some medical plant extracts. Advances in Environmental Biology, 10(2): 56-68.
NikbinVS, Aslani MM, Sharafi Z, Hashemipour M, Shahcheraghi F, Ebrahimipour GH (2012). Molecular identification and detection of virulence genes among Pseudomonas aeruginosa isolated from different infectious origins. Iranian Journal of Microbiology, 4(3): 118123.

Noguchi N, Suwa J, NaruiK, Sasatsu M, Ito T, Hiramatsu K, Song J (2005). Susceptibilities to antiseptic agents and distribution of antisepticresistance genes qacA/B and smr of methicillin-resistant Staphylococcus aureus isolated in Asia during 1998 and 1999.Journal of Medical Microbiology, 54:557-565.

Paulsen IT, Brown MH, Skurray RA (1996). Proton- dependent multidrug efflux systems. Microbiological reviews, 60:575-608

Pitt TL, Erdman YG (1977). The Specificity of agglutination reactions of Pseudomonas aeruginosa with $\mathrm{O}$ antisera. Journal of Medical Microbiology, 11: 15-23

Price LB, Stegger M, Hasman H, Aziz M, Larsen J, Andersen PS (2012). Staphylococcus aureus CC398: host adaptation and emergence of methicillin resistance in livestock. Microbiology journal, 3: 305-311.

Qin X, Emerson J, Stapp J, Stapp L, Abe P, Burns L (2003). Use of real-time PCR with multiple targets to identify Pseudomonas aeruginosa and other non-fermenting gram-negative bacilli from patients with cystic fibrosis. Journal of clinical Microbiology, 4: 4312-4317.

Quinn PJ, Markey BK, Carter ME, Donnelly WJ, Leonard F (2002). Veterinary Microbiology and 
Microbial Disease.Iowa State University Press, Ames, USA.pp.124126.

Reverdy ME, Bes M, Brun Y, Fleurette J (1993). Evolution of resistance to antibiotics and antiseptics of hospital Staphylococcus aureus strains isolated from 1980 to 1991. Pathologie Biologie, 41:897-904

Russell AD (2002). Antibiotic and biocide resistance in bacteria: introduction. The Journal of Applied Microbiology, 92: 1S-3S.

Saad ZA, Soad AN, Mahmoud E, Rehab E and Nashwa E (2017). Resistance patterns associated with bacterial pathogens causing omphalitis in baby chicks, journal of Bioscience Research. 14(4): 845-851.

Saif-Edin ME (1983). some studies on Pseudomonas infection in chickens. Thesis, Master of Veterinary Medicine university of Assiut, Egypt.

Schill F, Abdulmawjood A, Klein G and Reich F (2017). Prevalence and characterization of extended-spectrum beta-lactamase (ESBL) and AmpC betalactamase producing Enterobacteriaceae in fresh pork meat at processing level in germany. International. Journal of Food Microbiology, 257: 58-66.

Shukla S and Mishra P (2015). Pseudomonas aeruginosa infection in Broiler Chicks in Jabalpur,international journal of extensive Research, 6: 37-39.

Spilker T, Coenye T, Vandamme P, Lipuma JJ (2004). PCR-based assay for differentiation of Pseudomonas aeruginosa from other Pseudomonas species recovered from cystic fibrosis patients. Journal of Clinical. Microbiology, 42: 2074-2079.

Tartor YH and El-naenaeey EY (2016). RTPCR detection of exotoxin genes expression in multidrug resistant Pseudomonas aeruginosa.Cellular and molecularbiology, 62 (1): 56-62.

Tischer M, Pradel G, Ohlsen K, Holzgrabe U (2012). Quaternary ammonium salts and their antimicrobial potential: targets or nonspecific interactions?.Chem Med Chem, 7(1): 22-31.

Tripathi P, Banerjee G, Saxena S, Gupta SM, Ramteke PW (2011). Antibiotic resistance pattern of Pseudomonas aeruginosa isolated from patients of lower respiratory. The Journal of Veterinary Advance, 3(7): 180-185

Venturi V (2006). Regulation of quorum sensing in Pseudomonas.FEMS, Microbiology Reviews, 30: 274-291.

Vieu JF, Allos G, Hassan-Massoud B, Santos-Ferreira MO, Tselentis G (1984). Is there a geographic epidemiology of serogroups $\mathrm{O}$ of Pseudomonas aeruginosa?.Bulletin de la Société de pathologie exotique, 77(3): 288-294.

Walker SE, Sander JE, Cline JL, Helton J (2002). Characterization of Pseudomonas aeruginosa isolates associated with mortality in broiler chicks. Avian Diseases 46: 10451050 .

Wang C, Zhan Q, Mi Z, Huang Z, Chen G (2008). Distribution of the antisepticresistance gene qacE delta 1 in 283 clinical isolates of Gram-negative bacteria in China. Journal of Hospital Infection, 69: 394-396. 
WHO (2015). Global Action Plan on Antimicrobial Resistance. Geneva: World Health Organization.

Winstanley C, Kaye SB, Neal TJ, Chilton HJ, Miksch S, Hart CA (2005). Genotypic and phenotypic characteristics of Pseudomonas aeruginosa isolates associated with ulcerative keratitis. Journal of Medical Microbiology, 54:519-526.

Xu J, Moore JE, Murphy PG, Millar BC, Elborn JS (2004). Early detection of Pseudomonas aeruginosa; comparison of conventional versus molecular (PCR) detection directly from adult patients with cystic fibrosis (CF). Annals of Clinical Microbiology and Antimicrobials, 3(1): 21.

Zhao WH, Chen GL, Ito R, Kimura S, Hu ZQ (2012). Identification of a plasmid-borne bla (IMP-11) gene in clinical isolates of Escherichia coli and Klebsiella pneumoniae. Journal of Medical Microbiology, 61: 246251.

Zmantar T, Kouidhi B, Hentati H, Bakhrouf A (2012). Detection of disinfectant and antibiotic resistance genes in Staphylococcus aureus isolated from the oral cavity of Tunisian children. Annals of Microbiology, 62: 123128. 